\title{
GENETIC SYSTEM CONTROLLING THE YIELD AND ITS COMPONENTS IN THREE BREAD WHEAT (TRITICUM AESTIVUM, L.) CROSSES
}

\author{
MOHAMED A. I.KHALED
}

Wheat Research Dept. Field Crops Research Institute, ARC, Egypt.

(Manuscript received 10 February 2013 )

\begin{abstract}
This investigation was carried out at El. Gemmeiza Agric. Res. Station, A.R.C, Egypt, during the three successive seasons, 2009/2010, 2010/2011 and 2011/2012 to study genetic variance, gene action, heterosis, inbreeding depression, heritability and genetic advance for grain yield and its components and some agronomic characters. Six populations (P1, P2, F1, F2, Bc1 and Bc2) for three crosses were used in this study coming from (P1x P3), (P2 x P4) and (P3 x P4). Analysis of variance showed significant differences among the studied generations' means for all studied traits. Scaling test showed that most studied characters were significant indicating the presence of nonallelic interaction.. Additive type of gene effect was significant either positive or negative for no .of spikes / plant, 100-kernel weight and grain yield /plant in the first and second crosses. Meantime, dominance gene effects was significantly positive for all studied traits except plant height, no. of spikes /plant and grain yield /plant in the second cross .Additive $x$ additive and additive $x$ dominance type of gene actions were significantly positive or negative for all studied traits in the three crosses except for no .of spikes / plant in the first and second crosses and 100-kernel weight in the second and third crosses. On the other hand dominance $x$ dominance type gene effect was found to be significant for all studied traits except plant height and 100kernel weight in the first and third crosses, respectively. Heritability for days to heading in narrow sense was high and nearly equal to its corresponding in broad sense. High estimates for hertibility in broad sense were accompanied by moderate value of narrow sense for no. of kernels /spike, 100 -kernel weight and grain yield plant in the three crosses.

The third cross gave the highest heterotic effect towards earliness for number of days to heading and number of days to maturity with moderate heritability in narrow sense and with genetic advance being 1.59 and 1.98 days for both characters, respectively .Significant positive heterotic effects relative to better parent was obtained for no . of kernels / spike , 100 kernel weight and grain yield in the second and third crosses .
\end{abstract}




\section{INTRODUCTION}

In Egypt, wheat ( Triticum aestivum L.) is the most important cereal crop. However, the gap between the local production and consumption is continuously increasing due to increasing the country population with limited cultivated area. It has become necessary to develop genotypes which characterized by superior performance ( Shehab EL- Din 1993).

Wheat breeders are interested in estimating the relative magnitude of the genetic variance and types of gene action involved in expression of characters. Therefore, breeders need information about the nature of gene action, heterosis, inbreeding depression, heritability and predicted genetic gain from selection for different characters related to grain yield and its components. Many investigators studied the type of gene effect in wheat and reported that dominance was relatively more important than additive for grain yield, while additive genetic effect was predominated in the expression of plant height and days to heading. Abul- Nass et al (1993) reported that, dominance component of gene action played an important rule in the genetic control for, number of spikes/plant, number of kernels/spike, 100-kernel weight and grain yield/plant. In addition, concerning the heritability as narrow sense, Hendawy (2003) and El-Sayed and El.Shaarawy (2006) reported that heritability estimates for yield and its components were medium to high. However, Hamada (2003), Tammam (2005) and Abd El-Majeed (2005) reported that, additive and dominance components of gene actions were detected for most studied traits.

The objective of the current study was to estimate gene effects, genetic advance, inbreeding depression and genetic coefficient of variation for seven traits in three bread wheat crosses by using their six populations i.e., $\mathrm{P}_{1}, \mathrm{P}_{2}, \mathrm{~F}_{1}, \mathrm{~F}_{2}, \mathrm{BC}_{1}$ and $\mathrm{Bc}_{2}$.

\section{MATERIALS AND METHODS}

The present study was carried out at El-Gemmiza Agric. Res. Station, A.R.C., Egypt, during the three successive seasons of 2009/2010, 2010/2011 and 2011/2012. Four bread wheat genotypes (Triticum aestivumL.) were chosen for this study on the basis of their genetic diversity and origin (Table 1 ).

In the first season of 2009/2010, three crosses were made among the parents to produce $F_{1}$ hybrid grains. The three crosses were $\mathrm{P}_{1} \times \mathrm{P}_{3}$ (cross 1 ), $\mathrm{P}_{2} \times \mathrm{P}_{4}$ (Cross 2 ) and $P_{3} \times P_{4}$ (cross 3). In 2010/2011 season, some of $F_{1}$ plants for each cross were backcrossed to produce the $\left(\mathrm{Bc}_{1}\right.$ and $\left.\mathrm{BC}_{2}\right)$. At the same time, some other $\mathrm{F}_{1}$ plants were selfed to produce $F_{2}$ seeds. In $2011 / 2012$, the six population seeds, i.e. $P_{1}, P_{2}$, $\mathrm{F}_{1}, \mathrm{~F}_{2}, \mathrm{BC}_{1}$ and $\mathrm{BC}_{2}$ of the three crosses were sown in a randomized complete block design with four replications. Each plot consisted of 20 rows, i.e., eight rows for $F_{2}$ seeds, two rows for each of $\mathrm{P}_{1}$ and $\mathrm{P}_{2}$ or $\mathrm{F}_{1}$ and three rows for $\mathrm{Bc}_{1}$ or $\mathrm{Bc}_{2}$. The rows were $3.0 \mathrm{~m}$ long, $30 \mathrm{~cm}$ apart and seeds were spaced $10 \mathrm{~cm}$ writhen rows.

Data were recorded on 25 individual guarded plants for $P_{1}, P_{2}$ or $F_{1}$ and 60 plants for each of $\mathrm{Bc} 1$ or $\mathrm{Bc} 2$ and 75 plants for $\mathrm{F}_{2}$ in each replicate for the studied characters, i.e., number of days to heading, number of days to maturity, plant height $(\mathrm{cm})$, number of spikes/plant, number of kernels/ spike, 100-kernel weight (gm) and grain yield/plant $(\mathrm{gm})$. All recommended field practices for wheat production were applied in all growing seasons. 
Table 1 . The pedigree of the four parents of bread wheat genotypes

\begin{tabular}{|l|l|l|}
\hline Parents & Pedigree & C.B 2009/10 \\
\hline$P_{1}$ & $\begin{array}{l}\text { KAUZ/BAV } \\
\text { CM103329-10M -030M -020M -010M -Y -010Y - 0M-0SY-0AP }\end{array}$ & Mexico \\
\hline$P_{2}$ & $\begin{array}{l}\text { PL//CM1170 A-955*2 /CNO79/3/BOW "S" 4 Sids \#6 CGM 7851 -3GM - } \\
\text { 1GM -0GM }\end{array}$ & Egypt \\
\hline$P_{3}$ & $\begin{array}{l}\text { KAUZ/PASTOR } \\
\text { CMSS93BOOO 25 S-484 -010M -010Y -010M -4Y -0M }\end{array}$ & Mexico \\
\hline $\begin{array}{l}\mathrm{P}_{4} \\
\text { Sids 12 }\end{array}$ & $\begin{array}{l}\text { BUC//7C/ALD/ 5MAYA74/ON //1160 -147//3/BB/G/4/ Chat,S, } \\
\text { /6MYA/VUL//CMH 74a-630/4*SX-SD7096-4SD-ISD-ISD-OSD }\end{array}$ & Egypt \\
\hline
\end{tabular}

\section{Statistical and genetic analysis}

To determine the presence or absence of non-allelic interactions, scaling test as outlined by Mather (1949) was used. The scalls A, B, C and D and their variance were calculated to test the presence of inter allic interaction.

The standard error of $A, B, C$ and $D$ was obtained by taking the square root of their respective variances. T-test was calcuteted by dividing the effects, of $A, B, C$ and $D$ by their respective standard error.

Type of gene effects estimated according to Gamble (1962) six parameter's model as follows:

$\mathrm{M}=$ Mean $=\mathrm{F}_{2}$, additive $(\mathrm{a})$, dominance $(\mathrm{d})$, additive $\mathrm{x}$ additive $(\mathrm{a} a)$, additive $\mathrm{x}$ dominance ( $a d$ ), dominance $x$ dominance $(d d)$. The amount of heterosis was expressed as the percentage deviation of $F_{1}$ mean performance forms the betterparent values. Inbreeding depression was calculated as the difference between the $F_{1}$ and $F_{2}$ means expressed as percentage of the $F_{1}$ mean, Wynn et al (1970). T-test was used to determine the significance of these deviations where the standard error (S.E) was calculated as follows:

$\overline{F_{1}}-\overline{B p} /\left(\overline{V F}_{1}+\overline{V B}_{p}\right)^{1 / 2}$

And S-E for inbreeding depression was estimated as following $\left.\overline{F_{1}}-\overline{F_{2}}=\overline{V F}_{1}+\overline{V F}_{2}\right)^{1 / 2}$ Heritability in both broad and narrow sense were estimated according to Mather (1949) and the predicted genetic gain from selection $(\Delta \mathrm{g})$ was calculated according to Johanson et. al. (1955).

\section{RESULTS AND DISCUSSION}

Means and variances of the seven traits in the three studied crosses of the six populations i.e. $\mathrm{P}_{1}, \mathrm{P}_{2}, \mathrm{~F}_{1}, \mathrm{~F} 2, \mathrm{BC}_{1}$ and $\mathrm{BC}_{2}$ are presented in Table (2).

. All studied characters showed significant genetic variance in $F_{2}$ plants in the three crosses, therefore other needed parameters were estimated i.e., simple scaling test as outlined by Mather (1949) and the test of the presence of non-allelic interaction was estimated.

In general, the mean performance values of $P_{2}$ and $F_{2}$ in cross 1 and $F_{2}$ in cross 2 and $F_{1}, P_{1}$ and $F_{2}$ in cross 3 were the earliest in days to heading. At the same time $P_{2}, B C_{1}$ and $\left(P_{1}\right.$ and $\left.F_{2}\right)$ were the best as early maturing for the three crosses 1,2 and 3 , respectively. 
For plant height, $\mathrm{P}_{1}$ in crosses 1,2 and 3 had the highest values. For number of spikes/plant, $\mathrm{BC}_{1}, \mathrm{P}_{2}$ and $\mathrm{P}_{1}$ had the highest values for the crosses 1,2 and 3, respectively. On the other hand, $P_{1}, P_{2}$ and $F_{1}$ were the highest in number of kernels/spike in the crosses 1,2 and $3 . \mathrm{BC}_{2}, \mathrm{~F}_{2}$ and $\mathrm{F}_{1}$ have the heaviest kernel weight for the crosses 1, 2 and 3, respectively. Meanwhile, BC1 in cross 1 and P2 in cross 2 and $\mathrm{BC} 2$ in cross 3 recorded the highest grain yield / plant.

The choice of the most efficient breeding procedures depends, to a large extent, on the knowledge of the genetic system controlling the characters to be selected. The estimates of various types of gene effects contributing to the genetic variability are presented in Table (3).

Scaling test A, B, C and D in Table (3) showed that all the studied characters in the three crosses were significant except six out of eighty four estimates. These results in general, indicated the presence of non-allelic interaction. On the other hand, if scaling test $A, B$ and $C$ were significant, this may indicate the inadequacy of the simple model in computing the differences between populations. Also, the scaling test for the excepted traits (insignificant ones) indicated the absence of non-allelic interactions and have the additive-dominance model is adequate. These results are in agreement with those of Hamada (2003), Tammam (2005) Abd El-Majeed (2005), and Hendawy et al.(2009) .

The estimated mean effect of F2 $(m)$, which reflects the contribution due to the overall mean plus the locus effects and interactions of the fixed loci, was found to be highly significant.

Additive gene effect (a) was positive and significant for plant height and 100kernel weight in the second cross and no. of spikes/plant and grain yield/plant in the first cross and no. of kernels/spike in the third cross. On the other hand, it was negative and significant for days to heading, no. of spikes/plant and no. of kernels/spike in the second cross and days to maturity and grain yield/plant in the second and third crosses and plant height in the first and third crosses and 100-kernel weight in the first cross. These results indicated that the potentiality of improving the performance of these traits using the pedigree selection program may be more effective, Abul-Nass et. al. (1993) and Hendawy (2003).

In autogamous crops, i.e., wheat and barley, the breeder is usually aiming to isolate parental combinations that are likely to produce desirable homozygous segregates. The utility of attempts in identifying such pure lines is facilitated by the preponderance of additive genetic effects in self pollinating crops,( Joshi and Dhawan,1966) .

The estimates of dominance (d) effects were significant for all studied traits. The estimates of dominance were positive and significant for days to heading and no. of kernels/spike in the three crosses, days to maturity, 100-kernel weight and grain yield/plant in the first and third crosses, plant height in the second cross and no. of spikes/plant in the first cross. They were negative and significant for days to maturity, 100-kernel weight and grain yield/plant in the second cross, plant height in the first and third crosses and no. of spikes/plant in the second and third crosses.

These results indicate the importance of dominance gene effects in the inheritance of these traits. On the other hand, significance of additive (a) and dominance (d) components indicated that both additive and dominance gene effects were important in the inheritance of these traits. Also, selecting desirable characters 
may be practiced in the early generations but it would be effective in the late ones. Similar results were obtained by Hendawy (2003) and Moussa (2010).

Estimates of epistatic gene effects, additive $\mathrm{x}$ additive (aa), additive $\mathrm{x}$ dominance (ad) and dominance $x$ dominance (dd) are presented in Table (3). Significant estimates of epistatic gene effects for one or more of these three types of epistatic gene effects in the three crosses for all studied traits were detected.

Additive $x$ additive (aa) gene effects were positive and highly significant in days to heading and no. of kernels/spike in the three crosses, for days to maturity, 100-kernel weight and grain yield/plant in the first and third crosses, plant height in the second cross and no. of spikes/plant in the first cross. Meanwhile, it was negative and significant in case of days to maturity, 100-kernel weight and grain yield/plant in the second cross, plant height in the first and third crosses and no. of spikes/plant in the second and third crosses. These results indicated that the materials used in this study to detect and investigate inheritance of these characters could not be effective except in the case of days to maturity and plant height in which selection will be effective in identifying early dwarf lines .Similar trends were obtained by Hendawy (2003)and Moussa (2010).

Data concerning the epistatic gene effects, additive $\mathrm{x}$ dominance (ad) revealed different positive and significant estimates in the second and third crosses for heading date, plant height and 100-kernel weight, and in the third cross for days to maturity and no. of kernels/spike and for grain yield/plant in the first and third crosses. They also were negative and significant in the first cross for all studied characters and in the second cross for grain yield / plant. These results indicated that the inheritance of these traits was affected by the type of epistatic genes.

The dominance $x$ dominance (dd) gene effect differed according to crosses and characters. Number of spikes/plant, number of kernels/spike and 100-kernel weight were positive and significant in the second and third crosses, and negative and significant in the first cross. Maturity date and plant height were positive and significant in the second and third crosses, respectively. Days to heading and grain yield/plant were negative and significant in the three crosses. Positive and significant results confirm the important role of dominance $x$ dominance gene interactions in the genetic system controlling these characters. Similar results were reported by Singh et. al. (1985), Tamm am (2005) and Hendawy et. al. (2009).

The absolute relative magnitude of the epistatic gene effects to the mean effects was somewhat variable depending on the cross and the studied trait. Generally, the absolute magnitude of the epistatic effects was larger than additive or dominance effects. Therefore, it could be concluded that homozygous $x$ homozygous and heterozygous $x$ homozygous non-allelic interactions were more important than the heterozygous $x$ heterozygous interaction in the inheritance of most studied traits. The study further revealed that epistatic gene effects were as important as additive and dominance gene effects for most of the traits. Thus, the system of inbreeding employed in exploiting any character depends on the gene action involved in its expression for predicted gain in selection progress (Abul-Naas et. al. 1993).

\section{Heterosis}

In self pollinated crops, such as wheat, plant breeders have been investigating the possibility of developing hybrid cultivars. Thus, the utilization of heterosis in various crops through the world has tremendously increased the production either for human food or livestock feed. Heterosis is a complex 
phenomenon which depends on the balance of different combinations of genotypic effect as well as the distribution of plus and minus alleles in the parents. Heterosis is expressed as the percentage deviation of $F_{1}$ mean performance from the better or mid parent of the traits. Better-parent for plant height was the short one and heterosis relative to the mid-parent value may be also effective. On the other hand, early heading and maturity may be preferable for developing genotypes characterized by early maturing and high grain yield.

In this concern, percentage of heterosis over better parent values is presented in table (4). Negative significant heterosis was obtained for days to heading in the third cross. Therefore, this cross can be utilized in breeding for early heading. Plant height heterosis value in the third cross was also negative and significant, so they were suitable for breeding dwarf plant. The second cross had positive and significant heterosis values for no. of spikes/plant, no. of kernels/spike and grain yield/plant being $14.45 \%, 12.26 \%$ and $5.31 \%$, respectively. Also, positive and significant heterosis was obtained for 100-kernel weight in the first and second crosses. These results are in agreement with those obtained by Hamada (2003), Hendawy (2003) and Moussa (2010). Significant and positive better parent heterosis effects for grain yield/plant which was obtained in the third cross, could be considered as a promising one in wheat breeding program when planning for producing a hybrid wheat.

\section{Inbreeding depression}

Inbreeding depression measures the reduction in performance of the $F_{2}$ generation due to inbreeding. The results in Table (4) showed significant positive values for days to heading in the first and second crosses. Days to maturity in the third cross, no. of spikes/plant in the second cross, no. of kernels/spike in the second and third crosses, 100-kernel weight in the first and second crosses and for grain yield/plant in the second crosses. On the other hand, significant negative inbreeding depression values were detected for days to heading and plant height in the third cross, no. of spikes/plant and grain yield/plant in the first and third crosses, no. of kernels/spike in the first cross and for 100-kernel weight in the second cross.

Significant effects for both heterosis and inbreeding depression were associated with days to heading, maturity and plant height in the third cross, no . of spikes/plant and kernels/spike in the three crosses, 100-kernel weight in the first cross and for grain yield/plant in the first cross. Significant effects for both heterosis and inbreeding depression seems logic since the expression of heterosis in $F_{1}$ was followed by considerable reduction in the $F_{2}$ performance. Also, reduction in values of non-additive genetic components is logically caused by means of inbreeding depression. These results were in agreements with those obtained by Abul-Naas et. al. (1993) , Hendawy (2003), El-Sayed and El-Shaarwy(2006) and Moussa (2010).

\section{Heritability}

Assessment of heritability of various traits is of considerable importance in crop improvement program, for example, to predict the response to selection, Nyguist (1991) and to identify optimum environment for selection, Allen et. al. (1978), Heritability has been estimated in several experimental situations in literature.

Heritability estimates depending on magnitudes of its genetic variance components of additive and dominance are presented in Table (4). The highest broad sense heritability values were obtained for days to heading $(84.66 \%)$, kernel weight $(77.9 \%)$ and grain yield $(41.52 \%)$ in the second cross. Meanwhile, the lowest 
estimate was resultant for no. of kernels/spike in second cross (27.97\%). Heritability in narrow sense as estimated by using $F_{2}$ and backcrosses data, were low for plant height, no . of spikes/plant, 100-kernel weight and grain yield in the first cross with values $8.84 \%, 23.28 \%, 36.67 \%$ and $14.6 \%$, respectively, and high in the third cross for days to maturity $(70.87 \%)$, medium for no. of spikes/plant $(59.1 \%)$, and low for no . of kernels/spike (20.92\%) and 100-kernel weight(46.79\%).

The results revealed also that the genetic variance was mostly attributed to the additive effects of genes for the other studied traits. This confirms the previous results found by means of gene action estimates of additive genetic portion, which was mostly predominant. These results are in harmony with those obtained by ElHosry et. al. (1997), Hendawy (2003), and Moussa (2010).

\section{Genetic advance}

The genetic advance as percentage of the $F_{2}$ mean for the studied characters is presented in Table (4). Moderate to high genetic advance $(\Delta \mathrm{g} \%)$ was detected for number of spikes/plant, number of kernels/spike, 100-kernel weight and grain yield/plant for the three crosses, however, low genetic advance was obtained for days to heading , days to maturity and plant height for the three crosses .

In the present work, high genetic advance was found to be associated with high heritability estimates for no. of spikes / plant, 100-kernel weight and grain yield / plant in the three crosses. Therefore, selection in that particular population should be effective and satisfactory in the early generations for successful breeding purposes. Also, moderate and low genetic advance was found to be associated with moderate or low heritability estimates.

As it is well known, expected improvement via selection is directly proportional to heritability. This figure is a measure of low total variability in these traits and therefore reflects the total response that could be realized by breeding techniques. It is possible to visualize a situation where the heritability is high but little response can be expected, El-Hosary et. al. (1997), El-Sayed and El-Shaarawy (2006), and Moussa (2010). 


\section{REFERENCES}

1. Abd El-Majeed, S.A. 2005 . Estimation of epitasis additive and dominance variation in some bread wheat (Triticum aestivum L) cross. J. Agric. Sci., Monsoura Univ., 30 (6) : $2999-3011$.

2. Abul - Nass, A.A., M.A. Mahrous and A.A. El Hoseary 1993. Genetical studies on grain yield and some of its components in barley (Hordeum valgar L.) Egypt. J. Agron., 18 (1-2) 33-46.

3. Allen, F.L., R.E. Comstock and O.C.Resumes 1978. Optimal environment for yield testing. Crop. Sci., $18:$ 747-751.

El-Hosary, A., M.B. Habeeb and A.I. Fahmi 1997. Genetic studies of some quantities characters in soybean (G/ycine max L.). Menufiya J. Agric Rec., 22 (2) : $405-419$.

4. El-Sayed, E.A. M and G.A. El. Shaarawy 2006. Gentical studies on yield and some agronomic characters in some bread wheat (Triticum aestivum L.) crosses. J. Agric. Sci., Mansoura Univ., 30 (8) : 4901-4914.

5. Gamble, E.E. 1962. Gene effects in corn (Zea mays L.) separation and relative importance of gene effects for yield. Canadian J. Plant Sci., 42: 339-348.

6. Hamada, A..A. 2003. Gene effect for some agronomic traits in three bread wheat crosses. Annals Agric. Sci., Ain Shams Univ., Cairo 48 (1): 131-146.

7. Hendawy, F.A., H.A. Dawwam, M.A.Abo Sheriff and E. L. El- Massry (2009). Detection of epistasis in the inheritance of grain yield and its components in bread wheat ( Triticum aestivum.L)using triple test cross analysis. Menufiya J. Agric. Res., 34 (2) : 625- 640.

8. Hendawy. H.. 2003. Gentic architecture of yield and its components and some other agronomic traits in bread wheat. Menufiya J. of Agric. Res., 28 (1) : 71-86.

9. Johanson, H.W., F. Robinson and R.E. Comstock 1955. Estimation of genetic and environmental variability in soybeans. Agro. J., $47: 314$.

10. Joshi., A.B. and N.L. Dhawan 1966. Gentic improvement in yield and special reference to self -fertilized crop. India J. Genet and plant bread., 26-101.

11. Mather, K. 1949. Biometrical Genetics, Dover publ. Inc. London.

12. Mousaa, A.M. 2010. Estimation of epistasis, additive and dominance variation in certain bread wheat ( Triticum aestivum L.) crosses. J. plant prod., Mansoura Univ, Vol. (12): 1707-1719.

13. Nyguist. W.E. 1991. Estimation of heritability and prediction of response in plant populations CRC Critical Reviews in plant science, 10 (3) : 235- 322.

14. Shehab El- Din, T.M. 1993. Response of two spring wheat cultivars (Triticum aestivum L. em . Thell) to ten seeding rates in sandy soil. J. Agric. Sci., Mansoura Univ., 18: 2235 - 3240.

15. Singh. G., G. S. Bhullar and K.S. Gill 1985. Inheritance of some plant characters in an intervarietal cross of bread wheat. Crop improve., 12 (2) : 179-183.

16. Tammam, A. M. 2005. Generation mean analysis in bread wheat under different environmental conditions, Menufiya J. Agric. Res., 30 (3) : 937-956.

17. Wynn, J.C., T.A.Emery and P.W.Rice 1970. Combining ability in archis hypogeaen. Field performance of fihybrids. Cropsci., 10 713-715. 


\title{
النظام الوراثي المتحمم فى المحصول ومكوناته فى ثلاث هجن من قمح الخبز
}

\author{
محمد عبل الكريم اسماعيل خالا \\ قسم بحوث القمح - معرة بحوث المحاصيل- مركز البحوث الزراعية - الجيزة-مصر
}

أجرى هذا البحث فى محطة البحوث الزراعية بالجميزة فى ثلاث مو اسم زر اعية متتالية وهى

2010/2009 ، 2011/2010 و 2012/2011 لدراسة قوة الهجين و نوع الفعل الجيني ودرجة التوريث

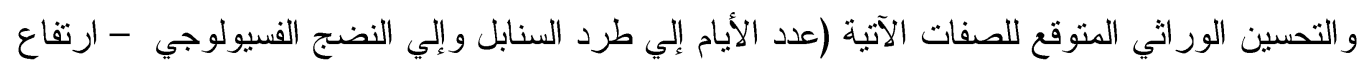

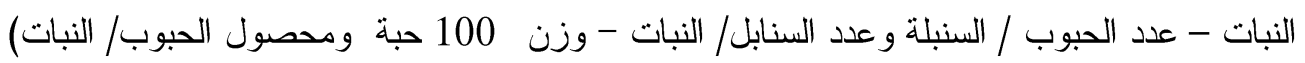

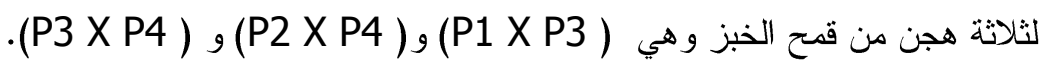
وتم تقييم العشائر الست لكل هجين فى تجربة قطاعات كاملة العشو ائية فى أربعة مكررات :

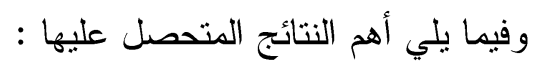

أظهر تأثير الفعل الجيني المضيف معنوية لمعظم الصفات عدا عدد الأيام إلي طرد السنابل

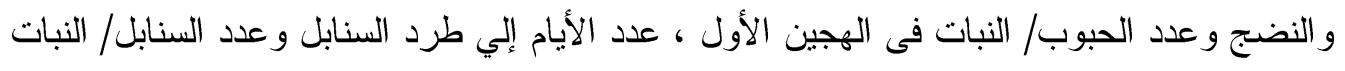
ووزن الألف حبة فى الهجين الثالث.

أظهر الفعل الجيني السيادي تأثير أعلي من الفعل الجيني المضيف بدرجة معنوية موجبة

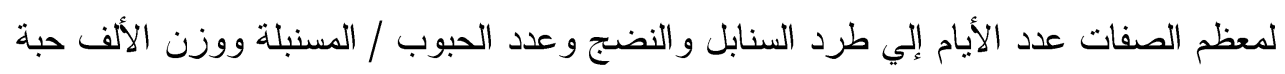

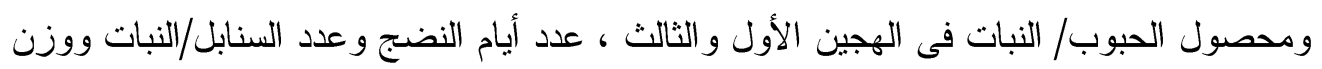
الألف جنيه ومحصول الحبوب ذات نأثير معنوي سالب فى الهجين الثاني. التفاعل الجيني من النوع (المضيف × المضيف) أظهر معنوية موجبة للصفات عدد الأيام

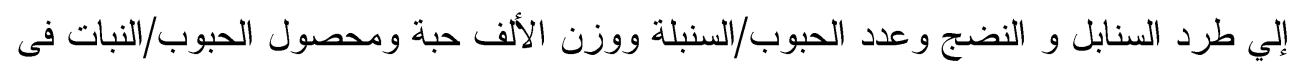

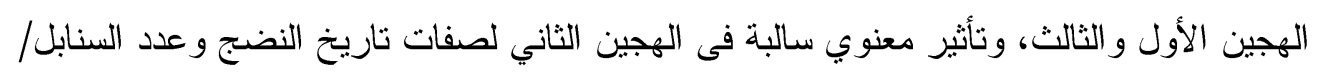
النبات ووزن الألف حبة ومحصول الحبوب/النبات.

التفاعل الجيني من النوع (المضيف ×السيادي) أظهر معنوية عالية لكل الصفات فيما عدا عدد

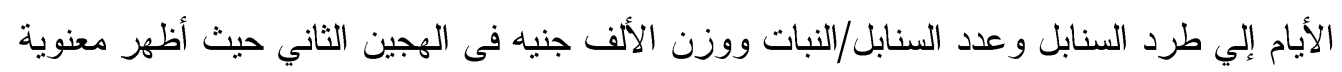

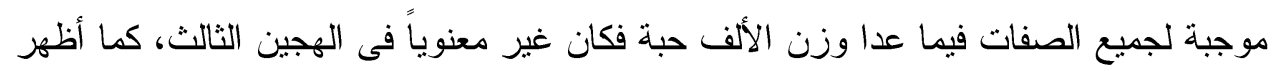

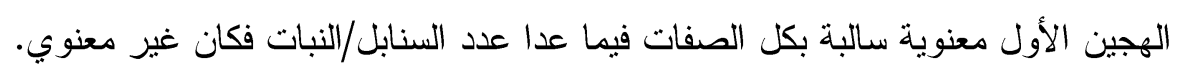

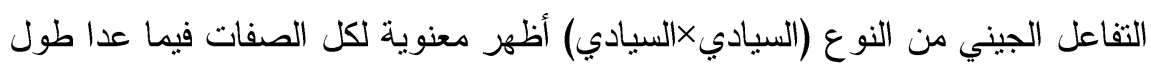

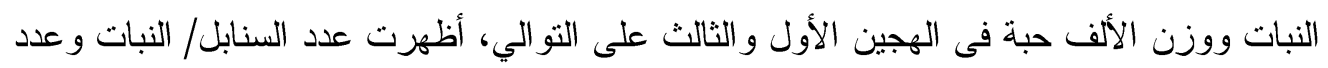

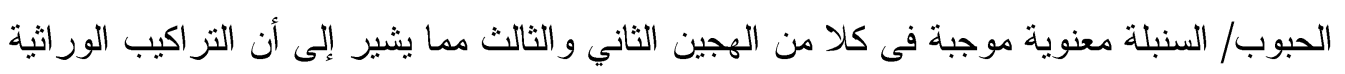
و المستعملة فى هذه الدراسة بها آلبلات ذات تأثير ات موجبة مما يجعل تحسين هذه الصفات بلات بالانتخاب فى الأجيال المبكرة فعال ومفيد.

قوة الهجين أظهرت معنوية سالبة عالية لصفة عدد الأيام إلي طرد السنابل وطول النبات فى وفئ الهجين الثالث، كما أظهرت قوة الهجين معنوية موجبة لصفات عدد السنابل/النبات وعدد 
الحبوب/السنبلة ووزن الألف جنيه ومحصول الحبوب في الهجين الثاني والثالث بينما كان وزن الألف حبة غير معنوي فى الهجين الثالث. وجدت تأثثرات سالبة ومعنوية بين قوة الهجين و التربية الداخلية ومتلازمة بين عدد الأيام إلي

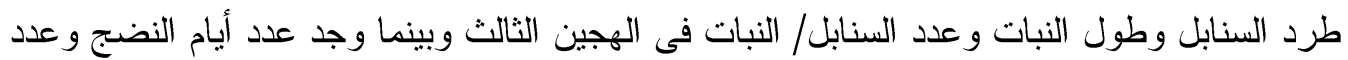
الحبوب/السنبلة ووزن الألف حبة فى الهجين الثالث تلازماً موجباً، وتلازماً سالب ومعنوياً لكل من ونابن

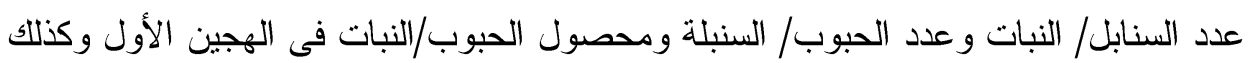
أظهر عدد السنابل وعدد الحبوب ومحصول الحبوب/ النبات تلازماً موجباً فى الهجين الثاني.

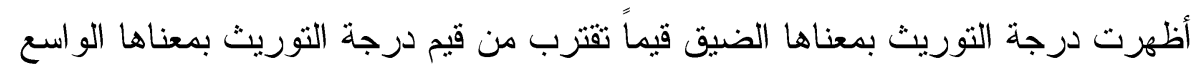

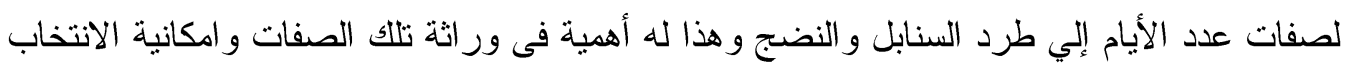
لها فى الأجيال المبكرة وتز اوحت هذه القيم بــين (184.66\%)، (70.87\%) على الترنيب. كما أظهرت درجة التوريث بمعناها الو اسع قيم مرتفعة ومنخفضدة لمعظم الصفات ما بين ( 27.97\% إلى إلى

أظهرت النتائج وجود تلازم بين صفتي وزن 100 حبة ومحصول الحبوب وبين درجة

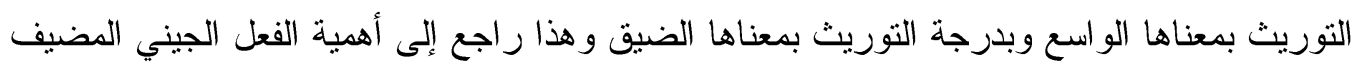
بالاضافة إلى الفعل الجيني غير المضيف فى ور اثة تلك الصفات.

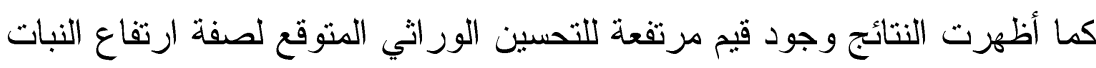
ومحصول الحبوب/ النبات ومحصول الحبوب/النبات فى الهجين الثاني و الثالث بينما كان التحسين الور اثي المتوقع ذو قيم متوسطة لصفة عدد السنابل/النبات و عدد الحبوب/النبات وزن 100 حبة فيى لونين

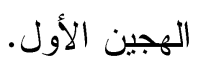

يمكن الاستفادة من هذا البحث من خلال الانتخاب فى الأجيال الانعز الية المبكرة لصفة التبكير والمحصول وذلك للحصول على سلالات مبكرة النضج و عالية المحصول. 